\title{
The Tambani project: A computer animation of The Greedy Hippo
}

\author{
Authors: \\ Rita M.C. Swanepoel ${ }^{1}$ \\ Christiaan van der \\ Westhuizen $^{1}$

\section{Affiliations:} \\ ${ }^{1}$ School of Communication \\ Studies, North-West \\ University, Potchefstroom \\ Campus, South Africa

\section{Correspondence to:} \\ Rita Swanepoel \\ Email: \\ rita.swanepoel@nwu.ac.za \\ Postal address: \\ Private Bag X6001, \\ Potchefstroom 2520, \\ South Africa \\ Dates: \\ Received: 08 Sept. 2011 \\ Accepted: 23 Apr. 2012 \\ Published: 13 Nov. 2012 \\ How to cite this article: \\ Swanepoel, R.M.C. \& Van der \\ Westhuizen, C., 2012, 'The \\ Tambani project: A computer \\ animation of The Greedy \\ Hippo', Literator 33(1), \\ Art. \#27, 10 pages. http://dx \\ doi.org/10.4102/lit.v33i1.27 \\ Note: \\ This article was written \\ as part of, and functions \\ within the scope of a \\ larger research project \\ entitled Transgressions and \\ boundaries of the page: $A$ \\ transdisciplinary exploration \\ of a practice-based research \\ project by means of the \\ artist's book conducted by \\ the subject groups Graphic \\ Design, Creative Writing \\ and Art History at the \\ Potchefstroom Campus of \\ the North-West University, \\ South Africa.
}

Project web page: www. bookboek.co.za

C 2012. The Authors. Licensee: AOSIS OpenJournals. This work is licensed under the Creative Commons Attribution License.
This article presented an investigation of and reflection on the techniques and production processes used to transform a traditional Ngano Venda folktale, The Greedy Hippo, from embroideries into a digitally animated film. The article was guided by a method derived from a practice-based research model for creative production which describes ways in which creative outputs can be regarded as a viable research option. The method comprised the documentation of and reflection on the project in three phases, namely pre-production, production and postproduction. The Tambani embroidery project is a community outreach initiative launched by Ina le Roux. Ngano is the collective noun for traditional Venda folklore. In this article, we argued that computer animation techniques could be implemented successfully in the digital transformation of a Venda folktale that was originally part of an oral tradition. We demonstrated this argument by means of Christiaan van der Westhuizen's transformation of The Greedy Hippo folktale into a computer animation format.

Die Tambaniprojek: 'n rekenaaranimasie van Die hebsugtige seekoei. Hierdie artikel bied 'n ondersoek na en refleksie op die tegnieke en die produksieprosesse wat gebruik is in die omskakeling van 'n tradisionele Ngano-Venda-volksverhaal, Die hebsugtige seekoei, vanaf borduurwerk in 'n digitale animasiefilm. Die artikel word gerig deur 'n metode wat afgelei is uit 'n praktykgebaseerde navorsingsmodel vir skeppende uitsette. Hierdie navorsingsmodel omskryf wyses waarvolgens skeppende uitsette as geldige navorsingsopsies gereken kan word. Die metode bestaan uit die dokumentering van en refleksie ten opsigte van die projek in drie fases, naamlik pre-produksie, produksie en post-produksie. Die Tambaniborduurwerkprojek is 'n gemeenskapsuitreikingsinisiatief wat deur Ina le Roux van stapel laat loop is. Ngano is die versamelwoord vir tradisionele Vendavolksverhale. In hierdie artikel argumenteer ons dat rekenaaranimasietegnieke wel suksesvol geïmplementeer word in die digitale omskakeling van ' $n$ Venda-volksverhaal wat oorspronklik uit 'n mondelinge tradisie stam. Ons demonstreer hierdie argument aan die hand van Christiaan van der Westhuizen se omskakeling van Die hebsugtige seekoei in 'n rekenaaranimasie.

There is no greater agony than bearing an untold story inside you. (Angelou 1969)

\section{Introduction}

This article reflects on the techniques and production process used to transform a traditional Venda Ngano folktale, namely The Greedy Hippo, from embroidered images into a digitally animated film (Van der Westhuizen 2010a). The article further proposes that this transformation process is also a form of transgression. The reason for this is that whilst the animation honoured the content of the folktale, it also adds a television viewer audience to the original audience, which is traditionally situated in an oral culture. The method that we apply in this article draws on a method derived from a practice-based research model for creative production that describes ways in which creative outputs can be regarded as a viable research option (cf. Gray \& Malins 2004:3). The method entails the documentation of and reflection on the project in three phases, namely (1) pre-production, (2) production and (3) post-production.

The Tambani embroidery project ${ }^{1}$ is a community outreach initiative that is managed by Doctor Ina le Roux ${ }^{2}$ from Johannesburg, South Africa. Tambani is situated south-east of Musina in the Limpopo Province in the towns of Fholovhodwe and Muswodi-Tshisimani. The Tambani project, within the context of the Transgressions and boundaries of the page project, entails that images derived from traditional Venda folklore have been translated into embroidered pictures (which are often made into quilts) by Venda women and then into a computer animation.

\footnotetext{
1.This project was invited to form part of the Transgressions and boundaries of the page project of 2009-2011 to which this edition of Literator is devoted.
}

2.Dr Ina le Roux is a retired lecturer. She did her PhD-thesis on Ngano folktales (Le Roux 1996) 
Ngano is the collective noun for traditional Venda folklore. Because the African tradition - especially in rural areas - is oral rather than written, Ngano stories are customarily told and retold from generation to generation by the oldest women in this particular rural area. The storytelling is accompanied by songs and light gestures of the hands and torso (Kruger 2007:4); therefore, Ngano is also known as song narratives.

The Tambani project does not only empower a group of disadvantaged rural African women economically, but also serves as a conservation tool for a tradition that is threatened with extinction (cf. Nefholovhodwe in Kruger \& Le Roux 2007:8). In this article, we argue that computer animation techniques can successfully be implemented in the digital transformation of a Venda folktale that was originally situated in an oral tradition. We demonstrate this argument by means of the transformation of The Greedy Hippo into a computer animation by Christiaan van der Westhuizen.

It has also become clear that the content of The Greedy Hippo shows a number of similarities with Western and European fairy tales (cf. Van der Walt's article in this edition of Literator). The possibility therefore exists that children from other cultures will also be able to enjoy and identify with the story of the Greedy Hippo. Van der Westhuizen's reason for choosing The Greedy Hippo for this animation is indirectly attributed to these similarities. Van der Westhuizen conceptualised an animation with children as the audience. Therefore, he argued that some of the other Ngano folktales were in certain ways too violent to be portrayed for an audience of children. He therefore decided upon The Greedy Hippo, as this story deals with children and can be translated into a digital animation without having to portray overtly violent scenes. In this regard, the remark of Kruger and Le Roux (2007) is significant:

Ngano that deal with gender relations in fact abound with violent, primordial images of male aggression. Particularly evocative are narratives that deal with abduction, rape and incest in which men are portrayed as marauding animals and monsters. These narratives correlate in many respects with ethnographic descriptions of the subjugation of women. (p. 11) (cf. Van Warmelo \& Phophi 1948:240-309)

The current article provides a brief discussion of the three-step practice-based research model which has guided the process of reflecting on the digital animation of the folktale. This is followed by a documentation of and reflection on the project.

\section{The practice-based research method}

The method that has been selected for this article has been derived from literature and graphic design projects, and entails three general phases that can be identified as central to almost any practice-based research model, viz:

- the pre-production phase, which entails the reflection on and contextual documentation of a project

- the production phase, that comprises the actual production as well as documentation of, and reflection on the creative production process

- the reflection on the entire process as post-production (cf. Scrivener 2000; Scrivener \& Chapman 2004; Gray \& Malins 2004; Combrink \& Marley 2009; Schön 1983).
Since practice-based research characterises a variety of creative fields, it is often not possible to delineate the processes in this type of research in a watertight manner. Furthermore, Gray and Malins (2004:40) state that it is often difficult - as a result of the fact that creative fields vary extensively - to determine a specific method before the actual creative process takes place. However, the above-mentioned three general phases (which are also appropriate for the current project) form the basis of most practice-based research models (Gray \& Malins 2004:40; Hasemann 2006). ${ }^{3}$

\section{Pre-production: Reflection on and contextual documentation of the project}

During this first phase the project is conceptualised. This entails conducting theoretical and contextual research and reflecting on how the project will be carried out on a practical level. During this phase, current issues, concerns and interests are identified (cf. Scrivener \& Chapman 2004; Combrink \& Marley 2009:192). Combrink and Marley (2009:192) further state that during this stage, the seed of the project grows out of discussions between practitioners (from one or more disciplines), and these may also involve the contributions of theorists such as art historians. From here, the idea is situated in the relevant context which allows one to link the idea to other pertinent issues and possible theoretical frameworks. This phase also entails developing a clear plan of action, whilst leaving room for change. The necessary funding applications and alterations of acquisition strategies to be applied throughout the project also need to be considered at this stage (cf. Scrivener \& Chapman 2004).

\section{Documentation of the production process}

The production phase consists of the documentation of the actual creative creation process. Scrivener and Chapman (2004) propose that this stage entails:

cycles of production of work reflecting the productive phase in terms of action and practice possible revision of issues, concerns and interests, possible search for resources relevant to modified issues, concerns and interests. (n.p.)

Combrink and Marley (2009:194-195) note that this step is the most intense, as the actual creative production takes place at this point. It is also during this phase that research-inpractice, in the form of reflective artists' journals, takes place. The production phase culminates in the presentation of the final creative research outcomes (artefacts), often in the form of an exhibition. However, in this case, the production phase culminated in the presentation of a computer animation.

\section{Reflection on post-production: Documentation and reflection on action and practice}

As the term post-production indicates, this is the phase where reflection on action and practice (i.e. on the project as a whole) takes place. This stage implies revisiting the documentation of the project, either by way of an academic article and a

3 An extensive range of publications by various authors has appeared on practicebased research, inter alia Gray \& Malins 2004; Scrivener 2004; Haseman 2006 based research, inter alia Gray \& Malins 2004; Scrivener 2004; Haseman 2006;
Brown 2000; Farber 2008; Combrink \& Marley 2009. Therefore, this article does not set out to provide a detailed explanation of practice-based research. 
catalogue or by way of a DVD (cf. Van der Westhuizen 2010b; Combrink \& Marley 2009:195). Scrivener and Chapman (2004) identify a fourth stage, namely reflection on action and practice (i.e. critical reflection on one's reflection). For the purpose of this article, however, these last two stages are combined into one, namely the post-production reflection.

We now proceed to a discussion of the pre-production stage, which entails contextual and theoretical research as well as the documentation of the animation process. The next section begins with contextualisation of the Venda people in South Africa. After this, the Tambani project is discussed and situated in the context of the Venda culture, followed by a discussion of Ngano folklore. This section concludes with an overview of the narrative content of The Greedy Hippo.

\section{Pre-production: Reflection and documentation of the Tambani project \\ Contextualisation of the Tambani project}

\section{The South African context}

The word Venda means world or land. It refers to the region where South Africa's Tshivenda-speaking people, also known as the Venda people. The region lies about $250 \mathrm{~km}$ from the Kruger National Park in the north-east of South Africa. The Limpopo River in the northern section forms part of the border between South Africa and Zimbabwe. Historians are uncertain as to where the Venda people originated. Kirkaldy $(2005: 15,16)$ is of the opinion that the ancestors of the Venda people settled in this region in the Early Iron Age. The tribe initially consisted of various clans, which united some 250 years later under the Singo rulers. Presumably, these rulers came from the north from near lake Malawi and subjected the people of this area, which would later come to be known as the Soutpansberg.

West (1976:89) states that the history of the Venda began with the Mapungubwe Kingdom in the 9th century, the first ruler of which was King Shiriyadenga, who was succeeded by his eldest son. By about 1250, Mapungubwe appears to have been abandoned and the people migrated to the Great Zimbabwe Kingdom (formerly Rhodesia). In Zimbabwe the former culture evolved into the Shona culture (Huffman 1973:353-366; cf. Kirkaldy 2005:17). According to the seminal writer on the Venda, Van Warmelo (1932:9), some of them left again and crossed the Limpopo back into South Africa under the leadership of Chief Dimbanyika. When Dimbanyika died, he was succeeded by his son Ndyambeu. These people eventually came to be known as the BaVenda or Venda people of South Africa. The Singo rulers and the Singo people formed the last major wave of immigrants to the area. They merged with the Tshivenda-speaking majority and were regarded as the 'original' or 'real' Venda (cf. Van Warmelo 1932:xx-xxviii; Kirkaldy 2005:17). Kikaldy (2005:16-18), however, emphasises that not all of the rulers were Singo in origin. According to this author, the Singo rulers and the Singo people were the last major wave of immigrants who merged with the Tshivenda-speaking majority (cf. also Kruger 2007:12).
The first contact between Venda and White people may have taken place around 1820 when this indigenous group encountered Portuguese hunters. During c.1835-1838, large semi-organised Afrikaner groups migrated from the Cape Colony to other parts of the country. The migration of these Afrikaner groups was spurred by their desire not to be ruled by the British colonial government. They also felt unsafe on the borders of the Cape Colony where they frequently clashed with the indigenous Xhosa people. They were called Voortrekkers and their large-scale migration is known as the Great Trek. Two Boer republics were established, namely the Zuid-Afrikaansche Republiek (ZAR) in 1852 in the erstwhile Transvaal - which at that time included the Limpopo area, and the Orange Free State (the current Free State) in 1877. During this period, several clashes and exchange transactions occurred between the Voortrekkers and the different indigenous groups (Giliomee 2003:101-102; 110-111). The arrival of White people eventually led to the subjection of the indigenous African people, as was also the case during the British Colonial era. ${ }^{4}$

In 1837 an Afrikaner Voortrekker group established themselves in the Limpopo area under the leadership of Louis Trichardt. In 1848 Andries Hendrik Potgieter and his group also arrived in the area (Kruger 2007:16-17; Kirkaldy 2005:20). Soon there was an increase of White people in the area.

The main source of income for the Soutpansbergers was ivory, and this gave rise to an elephant hunting industry (Kirkaldy 2005:21). The White inhabitants employed Venda people as hunters and workers, and they also illegally armed the local Venda people with firearms which they used to hunt elephants for them (Carruthers 1995:25-44; Storey 2008:110-111). In addition, White settlers often captured African children to work for them as so-called inboekelinge (Kirkaldy 2005:21-22) - these children were, in fact, slaves.

The Afrikaners lost their republics during the Anglo-Boer War (1899-1902) or the South African War (in Afrikaans it is called the Tweede Vryheidsoorlog, or Second Freedom War). The former republics became British colonies and were incorporated into the Union of South Africa in 1910. The country then consisted of four provinces: the Transvaal, Orange Free State, Cape Colony and Natal. On 31 May 1961, the country became a republic under the rule of the mainly Afrikaner National Party with Hendrik French Verwoerd (1910-1965) as prime minister. Verwoerd was generally known as the architect of apartheid. Black education was of a very low standard at the time and was vastly inferior to that of the White schools (Welsh \& Spence, 2007:284). In the rural areas, very little or no schooling was available to Black South Africans and therefore entire generations grew up illiterate. According to Verwoerd's homeland policy, all Black groups received their own states within the country; this era was known as a period of so-called 'self rule'. In this way, Venda became an independent state in 1980 (Welsh \& Spence 2007:284; Giliomee, 2003:606). Kruger (2007) offers the following insight:

4.This custom was continued and intensified when the mainly Afrikaner National Party with its apartheid policy took over the South African government in 1948. 
Venda became a nominally independent state ... headed by the party of traditional leaders [the Venda National Party]. This party suppressed political opposition and engineered the establishment of a one-party state in 1985 . This state failed to address the economic and democratic aspirations of large numbers of poor people. These people protested against inefficient leadership, political oppression, corruption and lack of material development by means of wide-spread strikes, protest marches and communal music-making. (p. 17)

South Africa became a constitutional democracy in 1994 when for the first time in the history of the country all its citizens were allowed to vote. The African National Congress - supported mainly by Black people - was voted into power under the leadership of Nelson Mandela. At the same time, Venda became part of South Africa again. In 1994, under the newly elected democratic government, the country was divided into nine provinces. The Limpopo Province was initially called the Northern Province, but was later renamed Limpopo Province.

\section{The cultural context}

Venda is generally known as the Land of Legends. According to Tiley-Nel (2008), the traditions of these people are steeped in myths, legends and mystery (cf. Van Warmelo 1932:7881; 111-126; West 1976:89-91; Kruger 2007:13-17; Tracey 1970:59-61). Venda people regard a number of specific places as sacred:

They believe that, through dances and ceremonies, they break with the mistakes of the past and embrace the future. Almost all ceremonies involve the calling of the ancestors ... In this African landscape legends are born by telling stories about the sacred water spirits, the hidden ancient burial sites and the revered ancestors. Venda combines antiquity, mystery and great scenic wonders, as century-old beliefs are intricately woven into the past and the present. (n.p.)

One such belief is called Ngoma Lungundu, or the drum of the dead. It is believed that one of the Venda ancestor kings, of Singo descent, could strike terror into the hearts of enemies who attacked the Venda people by beating his drum (Kirkaldy 2005:18). According to Venda belief, one can still hear this drum in the echoes of the cliffs at Mashovhela, which is one of the sacred places of the Venda. Venda culture incorporates a variety of Central African, Nguni and Sotho characteristics. Trade, intermarriage and war with Tsonga, Zulu, Swazi and other people also left imprints on the Venda culture.

Patriarchy is the cultural principle which has the strongest social influence on men and women (Kruger 2007:11). Du Plessis (1940:36) indicates that a Venda person's status is determined by patrilineal descent in marriage, inheritance and judicial matters. Kruger and Le Roux (2007:12) also note the importance of men in Venda culture. As far as the position of children is concerned, the eldest brother is endowed with the highest honour because he will become the future head of the homestead: 'The relationship between brother and sister is intimate [sic] and they help each other in times of need' (Kruger \& Le Roux 2007:12). The brother is regarded as the decision-maker and leader. This system helps to create a female Venda 'culture of silence' (Jeannerat 1997:95).
Ngano folktales refer to stories told by the elders in a village and is a form of indigenous knowledge passed from generation to generation. According to Van Warmelo's Venda dictionary (1995), the word Ngano means a story or tale (as also the words hadithi, kisa and hekaya). The root ngano is related to the verb anetshela, 'to narrate or to tell a story'. The word Ngano refers to the Venda form of the cante fable folklore category. Ngano is highly metaphorical in nature (cf. Kruger 2007:4), but Ngano performances do not involve dance or any overt dramatisation. Actions by the narrator are limited to small movements of the head, torso, arms and hands (Kruger 2007:23). Therefore Ngano can be characterised as a type of dramatised narrative (cf. Finnegan 1970:384).

Ngano are song stories stemming from pre-colonial times that provide listeners with a view on human relationships in an African society. As so-called 'small laws', Ngano offers moral instruction and upholds certain tenets of Venda customary law (Kruger \& Le Roux, 2007:15). Ngano folktales are characterised by the following:

[These folktales] like folklore elsewhere ... are ancient artistic maps of the human condition. ... They provide listeners with a ... view of human relationships in an African society. Their characters are enmeshed in a complex web of conflict and interdependency. Class, patriarchy, seniority and physical power are some bases from which the world is controlled. ... Men typically turn into marauding animals who hunt their human victims. Although the persecuted appear to be helpless, they are not denied redemption. They find refuge within the community of the vulnerable, while their physical frailty belies a spirit of rebellion that enables them to escape and even undermine those who abuse them (p. 7)

The usual performance settings associated with Ngano are kitchens and winter fires in the evening (Le Roux 1996:8). Kruger (2007:5) argues that this is the conventional time for the symbolic reconstruction of the world by means of dance, song and narrative, whilst Le Roux (1996:8) adds that the growing darkness of evening, with shadows on the walls in the flickering light of the fire, creates the necessary atmosphere. Usually, older women such as the grandmothers in the homestead act as narrators whilst the audience - other women and children [as co-performers] - respond with chants at short intervals. The narrator usually begins a story with the exclamation salungano!, often with increasing pitch, tempo and intensity. This exclamation means 'A story will be told' or 'Here comes a story'5 (Le Roux 1996:13; cf. Kruger \& Le Roux 2007:7). Kruger and Le Roux (2007:16) explain that salungano! draws attention to the fact that the story is fiction. Salungano! is a word that combines the phrase ho sala lungano, meaning 'only the story remains'. This is also an indication that the characters in the story live in a different dimension. Therefore, the word marks a symbolic space in which anything is possible.

Because the majority of Ngano narrators are elderly grandmothers, one can assume that the stories have been passed on from generation to generation and that the older women are regarded as bearers of wisdom. They are 5. Second translation is that of Kruger $(2007: 5)$. 
seen as the most important source of cultural habits, moral knowledge and lessons from the past in the community and as those with the most life experience. Female narrators indicate to Le Roux (1996:9) that the content of these stories is about their (the Venda people's) lives, customs and sufferings, especially of women and children, told in a metaphorical way. Only a few elderly Ngano narrators remain today. They may be some of the last exponents of a once-vital performance culture (cf. Kruger \& Le Roux 2007:7).

The Tambani project's aim is to empower a group of disadvantaged rural Venda women. The project was initiated and founded by Dr Ina le Roux, who conducted field research on Venda folk tales in the Limpopo region. She was especially interested in the role women played in narrating Venda folklore (Tambani 2002). Struck by their abject poverty, Le Roux turned the women's knowledge of folklore to practical use. In this process Le Roux acts as an agent for self-actualisation and economic empowerment. She designs and silkscreens scenes from Ngano narratives onto fabric and delivers the printed fabric to the women, who then embroider the images onto the fabric.

According to the Tambani website (2002), the name of the project was derived from the oldest narrator in the village of Muswodi. This woman was approximately ninety years of age at the time of her first meeting with Le Roux. Le Roux remarked that despite her age, the matriarch was still compos mentis and able to recount the earliest Ngano folklore in minute detail. About 65 women have vested interests in Le Roux's Tambani project. With the help of two supervisors, Le Roux distributes the silkscreened fabric and the necessary embroidery yarn and teaches the women embroidery techniques which they apply to the blocks of fabric that portray scenes from Ngano narratives.

The women produce almost 400 embroidered blocks monthly. The blocks are sewn together to form coverlets, table cloths and quilts, as well as wall decorations. Dresses and handbags are also made out of these embroidered blocks, and all the handmade products generated by the project are sold via the project's website. The products have also been exhibited and sold at local and international quilt shows (cf. Tambani 2002). In the process, the Ngano tradition has become known not only to its traditional Venda audiences, but also to a much wider national and international audience.

\section{The Greedy Hippo [The hippopotamus throws his weight around]}

The story ${ }^{6}$ begins with the usual salungano! after which the narrator, Sophia Nefolowhodwe, continues with, 'Now, there were two little orphans, a brother and sister. The brother was the eldest. He always went out to look for food. He left his little sister behind. He locked her in the house. When he returned, he sang:

6.The content of the story as told by Sophia Nefolovhodwe (in Kruger \& Le Roux 2007:144-145). The translation of the song into English is that of Kruger and Le Roux (2007).

\section{Kha mmoulele Luti! \\ Ndi nne, khaladzi yau! \\ [Sung by narrator] \\ Matshelo ndi ya mbalelo 7 \\ [Audience] (Kruger \& Le Roux 2007:144)}

Open the door, Luthi!

This is your brother!'

Every day followed the same pattern. The boy left their home, locked his sister in the house and ordered her not to open the door to anyone. Upon his return, the above chant is sung by the narrator and the audience. The little sister recognised his voice and opened the door for him. He went in and the children ate.

'A huge hippopotamus heard that boy singing. He came there. He wanted to eat that small child who was in the house. He ordered her to open the house in his gruff hippopotamus voice:
Kha mmoulele Luti!
Open the door, Luthi!
Ndinne...
This is your brother!'

[Narrator sings with a gruff voice].

The girl remained silent. 'This small child does not open the door', the hippopotamus complained. He went away. Then the brother came back.
Kha mmoulele Luti!
Open the door, Luthi!
Ndi nne...
This is your brother!'
[Narrator and audience sing in normal voices]
(Kruger \& Le Roux 2007:144-145)

The sister opened the door and her brother went in. They ate and ate and ate. The brother got up and left again. 'Ah!' the hippopotamus said, 'my voice is too gruff.' And so he sang like the little brother:
Kha mmoulele Luti!
Open the door, Luthi!
Ndi nne...
This is your brother!'
[Narrator and audience sing in normal voices].

'The child opened the door immediately, vuli! $!^{8}$ That [sic] hippopotamus went inside. He sat down.' 'Who does this plate belong to?' He asked. 'My mother!' the little sister replied. 'The hippopotamus swallowed it, kwiti!'And whose pot is this?' 'My mother's.' The hippopotamus swallowed all the things that belonged to the mother. Then he said, 'Whose child are you?' 'My mother's!' So he swallowed her too! Then he went back to the river, 'that hippopotamus, one of the water. Hah!' Then the brother returned. 'Open Luti!' Silence. 'Open, Luti, it is me, your brother!' Nothing. 'Hey, my mother's child has been eaten' he said worriedly. 'And so the brother made a musical bow.' Then he went to the river. When he got there, he sat on his heels.

$\begin{array}{ll}\text { Tsho la nyanwali wanga, } & \text { The one who ate my sister, } \\ \text { nga tshi de! } & \text { Let it come! } \\ \text { Nga tshi de tshi do nndya-vho, } & \text { Let him eat me too. } \\ \text { nga tshi de! } & \text { Let it come! } \\ \text { Tsho la khomba musidzana ndo lela } & \text { He ate the girl I raised' } \\ \text { [Narrator sings]. } & \\ \text { 'Nga tshi de! } & \text { Let it come!' } \\ \text { [Audience sing] } & \end{array}$

7.According to Kruger (2007:146), the meaning of this chant is unclear. He provides the following possible explanation: 'Perhaps tomorrow I will cut/tie switches'. Mbalelo refers to switches tied to a roof structure over which thatch grass is placed.

8.The meaning of the words vuli, as well as kwiti, nzutu, and kwashaa later in the text is not known and cannot be found in any dictionary. Presumably they are different exclamations, such as Aha! Oh! and the like. 
The boy sat there on his heels. He saw the water. It rippled. The hippopotamus started to come out' (Kruger \& Le Roux 2007:145).

$\begin{array}{ll}\text { Tsho la nyanwali wanga, } & \text { The one who ate my sister, } \\ \text { nga tshi de! } & \text { Let it come! } \\ \text { Nga tshi de } & \text { Let it come } \\ \text { Nga tshi de tshi do nndya-vho, } & \text { Let him eat me too. } \\ \text { nga tshi de! } & \text { Let it come! }\end{array}$

'The hippopotamus did as that boy wanted.' He came out and sat there. 'Can I sing for you with my musical bow ${ }^{9 \prime}$ the boy asked. 'Do it!' the hippopotamus replied.

$\begin{array}{ll}\text { Tsho la nyanwali wanga, } & \text { The one who ate my sister, } \\ \text { nga tshi de! } & \text { Let it come! } \\ \text { Nga tshi de tshi do nndya-vho, } & \text { Let him eat me too. } \\ \text { nga tshi de! } & \text { Let it come! }\end{array}$

'The stomach of that hippopotamus bulged. The boy had his musical bow, which was like a spear. Then he stabbed that stomach.' His sister escaped and dashed away, 'nzutu!' Those children ran home. 'That thing was left behind. He was finished, kwashaa!'

Ha mbo di vha ndi u fa ha lungano.'

This is the end of the story (Kruger \& Le Roux 2007:145).

\section{Similarities between The Greedy Hippo and European folktales: The case of Little Red Riding Hood}

This section provides a brief overview of tangential points between The Greedy Hippo and Little Red Riding Hood, in order to establish broad similarities between these stories.

The name of the brother is not mentioned. The reason for this is probably because the eldest brother is in Venda tradition (in the absence of the father) regarded as the head of the household and he should therefore be honoured as such. It should be noted that the same happens in traditional European fairy tales: the name of the hero who saves the victim, for instance the prince or the hunter ${ }^{10}$ in Little Red Riding Hood, is often not mentioned. ${ }^{11}$ Also, in both The Greedy Hippo and in Little Red Riding Hood the helpless female victims are swallowed by wild creatures - Luti by a hippopotamus and Little Red Riding Hood by a wolf.

According to Kruger and Le Roux (2007:146), the hippopotamus appears to be a symbol of the children's deceased mother's brother. The story suggests that he not only steals his dead sister's possessions, but also takes her daughter as his wife.

Narratives in which monsters swallow people who are subsequently rescued by a boy hero are commonly found in

9.Kruger and Le Roux (2007:146) point out that the use of the musical bow to stab the hippopotamus should not be taken literally. Instruments such as a musical bow are used to criticise the culprit publicly in the song and thus shame him into submission.

10.Cf. Van der Walt's article in this edition of Literator (2012) with regard to different versions of Little Red Riding Hood.

11.Feminist theories will be critical of this hero-role accorded to men. This point will not be discussed in the current artice, since the focus is on the techniques and production process of an animated film. For more information regarding an interpretation of Little Red Riding Hood, see Van der Walt (2012) in this edition of Literator.
Africa. If one takes into consideration that in Ngano songs, men often turn into marauding animals that hunt their human victims, this interpretation seems likely. It is also well-known that hippopotami are responsible for several annual fatalities in the Limpopo area (cf. Kruger \& Le Roux 2007:9; Walker 2008:5; Tracey 1970:98). The hippopotamus is indeed a notoriously dangerous animal. This notion of a threatening animal is a feature shared by traditional European fairy tales where the helpless female victim will often be saved by a man - usually a prince. In the case of the Ngano song, the little girl was saved by her brother. In the case of Little Red Riding Hood, the little girl was saved by the hunter. In Little Red Riding Hood the culprit is also, as in The Greedy Hippo, a male animal, as references to the wolf are in the masculine [he] form.

Interestingly, both the hippopotamus and the wolf in Little Red Riding Hood mime another character's voice in order to deceive a little girl.

\section{Production: The techniques used, and reflection and documentation of the Tambani project} The contextualisation of the animation process

Professor Jaco Kruger, a researcher at the School of Music at the North-West University, Potchefstroom Campus, first proposed to the organisers of the Transgressions and boundaries of the page project the idea of producing an animation from the embroideries of the Tambani project. The organisers, in their turn, indicated that Van der Westhuizen would be the ideal candidate for this project and that he should contact Dr Ina le Roux. The embroideries used for this digital animation were produced by Florah Kwinda, Eni Nenzhelele, Sani Mudau and Emmah Vhengani - all members of the Tambani project. These women's skills were instrumental in the creation of the animation. Le Roux acted as mediator between Van der Westhuizen and the Tambani women.

Animation, especially cell-based or frame-by-frame animation, has a relatively short but fascinating history. According to Mosley (2001), pioneers of animation include Winsor McCay of the United States and Emile Cohl and Georges Méliès of France (cf. Cavalier 2001; Solomon 1994:1). Winsor McCay (1869-1934) pioneered early frame-byframe (cell-based) animated films as we know these today. McCay's Gertie the Dinosaur (1914) is still considered by film and animation historians to be the first cartoon character created exclusively with a unique and 'realistic' personality (Canemaker 1987:24). It was this characterisation of the dinosaur that has led to the astounding popularity of the animation tradition (initially from Europe and America) and which paved the way for the success of most animation houses in the 20th century (cf. Canemaker 1987:39). 
Traditionally, cell-based or frame-by-frame animation is achieved by using multiple images that change or animate, in succession, over time. The techniques followed to produce these images usually entail clay models, paper cut-outs, paint, pencil or charcoal drawings that are drawn (or manipulated) and rubbed out, or altered. After each altered state, a picture is taken and this results in an animated montage of images (Canemaker 1987:39).

\section{Embroidery into animation}

Van der Westhuizen applied his knowledge of character animation to produce an animated short film by using the Venda Ngano folktale, in combination with the embroideries created by the women of the Tambani project.

At first, Van der Westhuizen received only four embroidered panels from the Tambani project (Figure 1). These embroidered blocks portray scenes from the original The Greedy Hippo. They illustrate the main moments of the Ngano narrative:

1. the hut the children live in

2. the hippopotamus

3. the spoons

4. the pot that the hippopotamus swallowed.

These images served as inspiration for the short animated feature that would illustrate The Greedy Hippo as told by a Ngano narrator. The panels were used as a rudimentary storyboard $^{12}$ and to process work from which Van der Westhuizen would construct the animation.

\section{Setting the premise and depicting characters}

As with most animations, setting up the premise and background for the story serves as the basis of any successful narrative (Wright 2005:118). In this project, the premise and characters were already present in the original folktale. The first set of embroidered panels, however, featured only the hippopotamus, the hut and the children's possessions.

The process then proceeded as follows: Van der Westhuizen used the pictures drawn by Le Roux. The pictures were silkscreened onto the cloth and then the women from the Tambani project embroidered the pictures onto the cloth. The same procedure was followed with the depiction of the boy and the girl, as well with the scenes that illustrate the Ngano song. This process resulted in a series of eight detailed panels.

One of the problems that had to be solved was that the initial silk-screened figures were quite static and that it was difficult to separate the characters from their embroidered environment, as can be seen in Figure 2, on the right.

The next step was to silkscreen frame-by-frame 'movements' of the characters' torsos to facilitate the application of the relevant animation techniques of simple movements by the characters.

12.A sequence of drawings, typically with some directions and dialogue, representing the shots planned for a movie, television or animation production.
The most basic animation technique conventionally entails two or more drawings where the character turns the position of his head or any other body part to convey or create the illusion of movement. In animation terms, these changes of character movement or behaviour are known as 'keys', whilst the actions that happen in between these 'keys' are referred to as tweens (cf. Williams 2001:47).

It was explained to Le Roux and the women of the Tambani project that it would be essential that all the characters' body parts must be embroidered separately, as these separate body parts would facilitate animating the key positions or poses that the characters would assume in the final animation, as can be seen in the four panels in Figure 3 (overleaf).

\section{Trekking to Venda}

Kruger (in his capacity as researcher and lecturer in the School of Music at the North-West University), wrote an article on Ngano music (cf. Kruger 2007). He accompanied Le Roux on a two-week excursion to the Limpopo Valley early in April of 2009 in order to document the processes of work during these embroidery sessions. In particular, Kruger documented the embroidery process the surroundings as well as the actual Ngano storytelling events that took place during Le Roux's subsequent workshops with the Venda women by means of photographs and videos. This documentation assisted Van der Westhuizen in gaining greater insight into both the context of the Tambani project and Venda culture. The documentation further served as a backdrop that Van der Westhuizen kept in mind when plotting the setting of the animation, and helped him to understand the richness of the folktale, which was also reflected in the texture and layering of the embroidery.

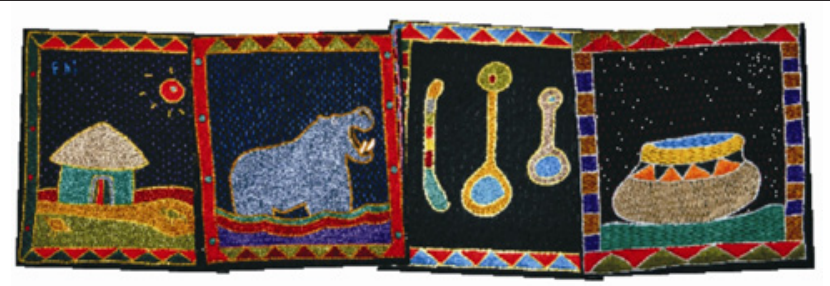

Source: Tambani, n.d., A Hippo Swallowed a Little Girl, from http://ibt.afrihost.com/ inatambani//welcome.php?mcat=Venda_Folktales\&scat=Hippo_Swallowed\&link=21\&wsS $D=a 3 f 37798203 a 30 a 13238 c 3 f d 9 e 5 f 982 d$

Permission to reproduce the image was obtained from the Noth-West University, Potchefstroom Campus, South Africa

FIGURE 1: The original embroidered panels which were designed for the animation.
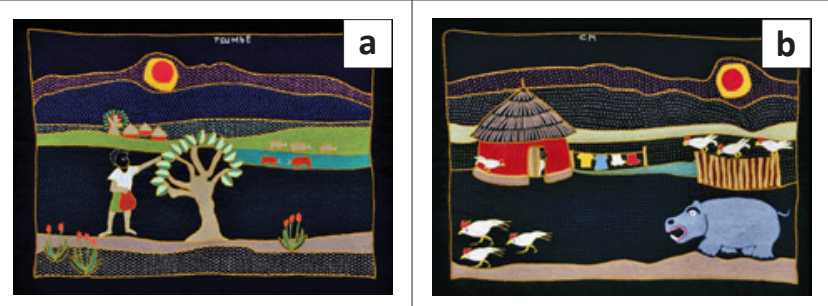

Source: Greyling, F., Marley, I. \& Combrink, L. (eds.), 2011, Transgressions and boundaries of the Page: Catalogue, Faculty of Arts, North-West University, Potchefstroom. Permission to reproduce the image was obtained from the Noth-West University, Potchefstroom Campus, South Africa

FIGURE 2: Embroidered panels created for the animation. 

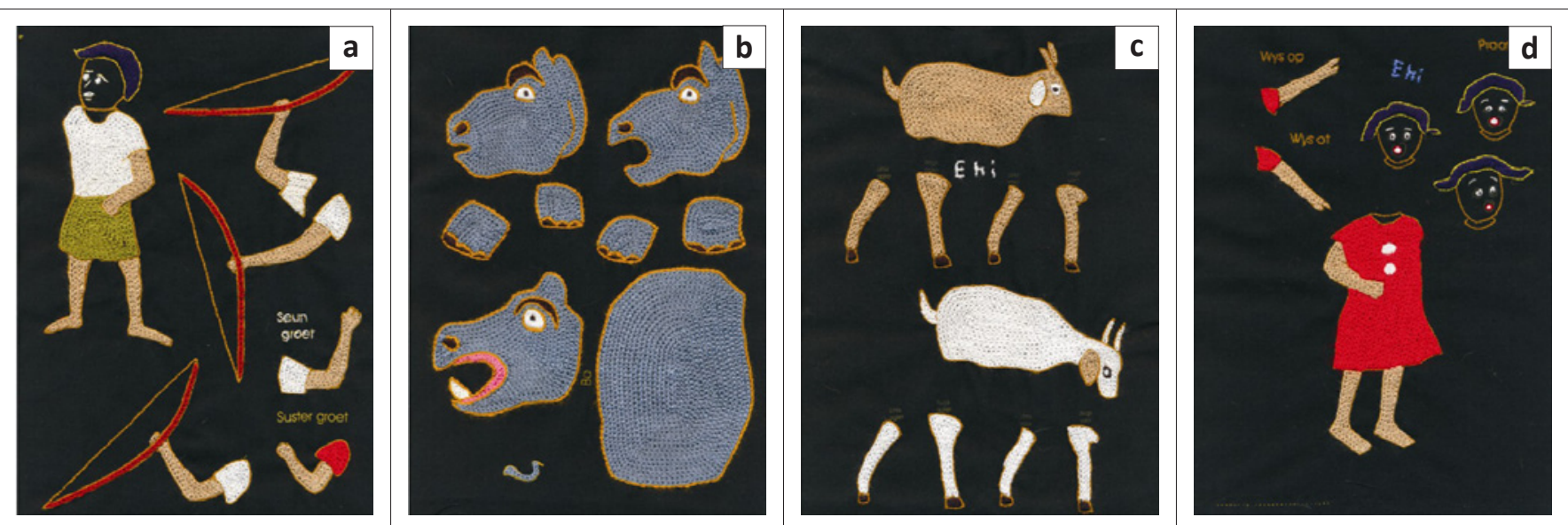

Source: Greyling, F., Marley, I. \& Combrink, L. (eds.), 2011, Transgressions and boundaries of the Page: Catalogue, Faculty of Arts, North-West University, Potchefstroom. Permission to reproduce the image was obtained from the Noth-West University, Potchefstroom Campus, South Africa

FIGURE 3: The four key panels created for the animation.

\section{Digitising needle work}

The embroideries were sent to Van der Westhuizen who then had to translate them into digital format. The key panels with the separate body sections of each character were masterfully crafted, stitch by stitch. Each flat embroidered panel is roughly the size of an A2 poster (420 mm wide by $594 \mathrm{~mm}$ high).

Van der Westhuizen's immediate concern was that of the digital documentation of the embroideries. It was felt that taking digital photographs of the panels would not do justice to the texture and colours of the thread and the quality of stitching. However, the scanner that was used had a flatbed area of an A4 page (210 mm wide by $297 \mathrm{~mm}$ high) size - much smaller than the images. It was decided to scan all the panels in sections at a very high resolution, which meant that each section had to be carefully demarcated with a small overlap or bleed area. Nonetheless, scanning the panels preserved the appearance of the stitching, texture, colour and depth that made up the embroidery work. Each section was then literally digitally 'stitched' together using Adobe Photoshop software, carefully aligning the bleed areas of the panels to overlap with each other, and then manipulating them in such a way that they resembled the originals as closely as possible. Thereafter each character section, prop, background, foliage and environment section was digitally cut from the digitised panels and arranged in layers, in order for the setting up of each scene to be 'acted out' by the digitised embroidered characters.

It is important to note that the embroidered panels also included a decorated embroidered border, which was later re-introduced into the animation as a framing device, as if the story was viewed through a window into the embroidered landscape. This frame also changed sequentially during the final animation. The frame helped to show whether the scene was being played out inside the hut, or outside in the field.

\section{Character rigging}

In animation, a character rig consists of a simple skeletal structure that mimics the movement of live motion. In most cases, these skeletal structures can be edited to create unique variables for different types of characters (Soranio 2011). Van der Westhuizen was faced with a unique problem as the skeletons of the characters featured in the Tambani project were initially quite rigid and appeared like stick figures. This perceived difficulty was turned into an advantage as the rigidity and stick-like movements of the characters were made to resemble those of a Ngano storyteller. Sensitively focusing on the repetition of certain hand and body movements and facial expressions honoured the Ngano storytelling tradition. To complete the character rigs, the various embroidered body sections of the characters were layered onto a basic skeleton using Adobe After Effects software, and then frame-by-frame animation was applied in order to generate the various walk cycles for each character. In animation terms, a walk cycle is a series of frames or illustrations drawn in sequence and made to loop in order to create an animation of a walking character. The walk cycle is looped repeatedly, and therefore it was not necessary to animate each step over and over again.

\section{Transforming an oral tradition into a digital computer animation}

In the original Ngano narrative, the hippopotamus is a metaphor for a family member who attempts to threaten, rob and destroy the estate of the two orphaned children. The Venda women depicted the hippopotamus' stark, almost threateningly wide eyes and open mouth in a very dramatic and convincing manner in their embroideries. A softening touch was added to the hippopotamus's antagonising nature by adding a brow and by adjusting the walk cycle of the hippopotamus's to add a swagger to his gait and swirl to his tail. The reason for these changes was that the animation was aimed at children, and it was felt that a greater sense of movement would be visually more compelling to this audience. Other walk cycles were also created on a smaller scale for cattle and livestock in the final animation.

Thereafter, the animated characters and scenes were carefully plotted out to match the traditional storyline and each scene of the story was animated separately. This was done so that small details could be added, such as the chickens pecking 
the ground in the third scene. Originally these chickens were stationary, but the pecking effect was added to reduce the rigidity of the traditional embroideries and to add a playful and vibrant feeling.

Other animated elements were also added to convey the notion of time passing, for example the sun introduces the beginning of the story by illuminating the opening scene, and flickering stars indicate night-time when the boy returns to the hut.

\section{The music for the animation}

Initially, Van der Westhuizen approached Kruger to discuss the possibility of including a traditional Ngano storyteller who could narrate the folktale. He also suggested that Kruger could assist in writing a musical score for the animation. However, due to time constraints, Kruger supplied a sample of music by the Venda artist Solomon Mathase from his album Venda Guitar Songs to be used by Van der Westhuzen at his discretion. Mathase's work typically deals with pain, suffering and loss (Olsen 2003:83) and was thus complementary to the content of the final animation.

\section{After the production phase}

On 14 July 2011 the organising committee of the Transgressions and boundaries of the page project arranged a colloquium where participants presented papers on the practice and processes of the various book projects. This was the first time that Van der Westhuizen shared the creative process of the animation project to an audience comprising mostly of academic delegates.

In October of the same year, during the Kenneth Kaunda regional libraries annual group meeting, Van der Westhuizen was invited to present his animation project to the local librarians who work specifically with children's books and literature. This was followed by another invitation for Van der Westhuizen to present the creative process of the animation project to a broader librarian audience. These last two events were attended by delegates from local, rural and international libraries, that ranged from community book centres in the Kenneth Kaunda district, South Africa, to the Linnaeus University in Växo, Sweden. Both events culminated in extensive discussions on the processes and the success of the animation project.

In January 2012, Van der Westhuizen presented a paper at the 6th International Design Principles and Practices Conference at the University of California, Los Angeles, in the United States. The title of the paper was The Tambani animation project: A cross-cultural investigation, and specifically focused on the differences in approach used by two diverse cultures for purposes of storytelling. Furthermore, the paper explored the processes used by Van der Westhuizen in an attempt to bridge this cultural divide by means of this animation project. Van der Westhuizen is preparing a written version of this paper for the conference's accredited proceedings.

\section{Conclusion: Post-production reflection on this article}

\section{Reflection on the method and arguments of this article}

This article applied a practice-based research method to present a reflection of the manner in which a traditional Venda Ngano folktale, The Greedy Hippo, was translated into a digitally animated short film. This method consists of three main phases, namely the documentation of, and reflection on, the project in three phases, namely (1) pre-production, (2) production and (3) post-production.

A central element in this reflection process is the recognition that the embroideries of the rural Venda women served as inspiration for, and were key to, the success of this project. Therefore, special care was taken throughout the production process not to alter the content of the original Ngano story.

\section{Contribution of the animation and of this article}

This animation of a Ngano story hopes to contribute towards the conservation of these traditional songs by telling the story to a wider audience, especially to children from Western or European cultures. The article also highlighted a number of similarities between Ngano songs and European fairytales, for instance the role of the man - whether a prince, brother or hunter - as the hero. ${ }^{13}$ Therefore, children from these cultures will perhaps be able to enjoy and identify with the way that good always triumphs over evil in fairy tales, as was also the case with The Greedy Hippo.

The community experiences and shared interests that are generated amongst the women of the Tambani project are also considered to be of great value and need to be reflected upon in an article such as this one. Not only did the project provide the women with a platform for sharing their daily experiences, it also created a sense of place and belonging amongst them and their immediate community, whilst imparting Ngano folklore.

This animation project, which is the central concern of the current article, hopes to make a contribution to the community as the diverse outcomes include job creation, celebration and memorialising the differences in language and culture. It also creates greater awareness and knowledge of the Venda culture and the particular community and community project, product development and marketing, as can be seen by the invitations that Van der Westhuizen received. The findings and impact of the project and article form part of the research conducted in the context of the Transgressions and boundaries of the page project.

The opportunity to create an animation in this innovative way also helped to create a unique experience that allowed the participants to transgress the boundaries of traditional 13.cf. Footnote 8 . 
artists' books within the Transgressions and boundaries of the page project. To our knowledge, this project was the first to transform a Ngano folktale into a digitally animated short film.

\section{Acknowledgements}

The authors would like to acknowledge Dr Ina le Roux, the embroiderers of the Tambani project, and Prof. Jaco Kruger (North-West University) for their initiative and contributions to the project.

\section{Competing interests}

The authors declare that they have no financial or personal relationships which may have inappropriately influenced them in writing this article.

\section{Authors' contributions}

M.C.[R.]S. (North-West University) was responsible for most of the contextual and background research. C.v.d.W. (North-West University) was responsible for the design and execution of the animation and also provided most of the technical research.

\section{References}

Angelou, M., 1969, I know why the caged bird sings, Random House, New York. Canemaker, J., 1987, Winsor McCay: his life and art, Abbeville Press, New York. Carruthers, E.J., 1995, Game protection in the Transvaal, 1846-1926, Government Printers, Pretoria. (Archives Year Book for South African History)

Cavalier, S., 2001, A short history of animation, viewed on 16 January 2012, from http://www.fi.edu/fellows/fellow5/may99/History/history.html

Combrink, L. \& Marley, I., 2009, 'Practice-based research: Tracking creative creatures in a research context', Literator, 30(1), 177-206.

Douglas, A., Scopa, K. \& Grey, C., 2000, Research through practice: positioning the practitioner as researcher - Working papers in art and design, viewed 30 August 2011, from http://www.herts.ac.uk/artdes/research/papers/vol1/douglas2.html

Du Plessis, H., 1940, 'Politieke organisasie van die Venda', MA-dissertation, University of South Africa, Pretoria. (Unpublished)

Grey, C. \& Malins, J., 2004, Visualizing research: A guide to the research process in art and design, Ashgate, Aldershot.

Greyling, F., Marley, I. \& Combrink, L. (eds.), 2011, Transgressions and boundaries of the page: Catalogue, Faculty of Arts, North-West University, Potchefstroom.

Finnigan, R., 1970, 'Oral literature in Africa', Oxford University Press, London.

Hasemann, B., 2006, 'A manifesto for performative research', Media International Australia incorporating Culture and Policy, theme issue Practice-Led Research $118,98-106$.

Jeannerat, C.F., 1997, 'Invoking the female vhusha ceremony and the struggle for identity and security in Shiendeulu Venda', Journal of contemporary African Studies 15(1), 87-106.
Kirkaldy, A., 2005, Capturing the soul: The Vhavenda and the missionaries, Protea Boekhuis, Pretoria.

Kruger, J., 2007, 'Songs of struggle: Dominance and resistance in Venda Ngano song narratives', Journal of Musical Arts in Africa 4(1), 1-27.

Kruger, J. \& Le Roux, I., 2007, The flamboyant rooster and other Tshivenda song stories, North-West University, Potchefstroom.

Kruger, J. \& Van Der Westhuizen, C.E., 2011, 'Die Tambaniborduurprojek', in F. Greyling, I. Marley, L. Combrink (eds.), Transgression and boundaries of the page, North-West University, Potchefstroom.

Le Roux, I., 1996, The Tambani project, viewed 29 July 2011, from www.tambani.co.za

Mosley, J., 2001, Compiled history of animation, viewed 16 January 2012, from http:// joshuamosley.com/UPenn/courses/Ani/AnimationHistory.html

Nefholovhodwe, S., 2007, 'Hippopotamus throws his weight around', in J. Kruger \& I. Le Roux (eds.), The flamboyant rooster and other Tshivenda song stories, pp. 144-148, North-West University, Potchefstroom.

Olsen, K., 2003, 'Venda Guitar Songs, Solomon Mathase: Review of recording', SAMUS: South African Journal of Musicology 23, 83-84.

Scrivener, S., 2000, Reflection in and on action and practice in creative production doctoral projects in art and design, Working papers in art and design, viewe 31 August 2011, from http://www.herts.ac.uk/artdes/research/papers/wpades/ vol1/scrivener2.htm

Scrivener, S. \& Chapman, P., 2004, The practical implications of applying a theory of practice based research: a case study, Working papers in art and design, viewe 31 August 2011, from http://www.herts.ac.uk/artdes/research/papers/wpades/ vol3/ssfull.html

Siyabona Africa, 2011, Venda, viewed 12 January 2012, from http://www.southafrica. org.za

Solomon, C., 1994, The history of animation, Random House, New York.

Soranio, M., 2011, Skeletal Animation - Bourns College of Engineering, viewed 31 August 2011, from http://alumni.cs.ucr.edu/ sorianom/cs134_09win/lab5.htm

Storey, W.K., 2008, Guns, race, and power in Colonial South Africa, Cambridge University Press, New York.

Tambani, 2002, The Tambani project, viewed 02 November 2011, from www.tambani. co.za

Tambani, 2010, The greedy hippo, viewed 10 Oktober 2012, http://www.bookboek. co.za/tambani.html

Tiley-Nel, S., 2008, 'Myfundi', The Venda culture, viewed 02 November 2011, from http://myfundi.co.za/e/Venda

Tracey, H., 1970, Chopi musicians; Their music, poetry, and instruments, Oxford University Press, London.

Van der Westhuizen, C.E., 2010a, The greedy hippo, viewed 10 October 2012, from http://www.youtu.be/k2f1kr7X9aM

Van der Westhuizen, C.E., 2010b, 'Website for Transgressions and boundaries of the page/Oor die einders van die bladsy', viewed 29 July 2011, from www.bookboek. co.za

Van Warmelo, N.J. (ed.), 1932, Contributions towards Venda history, religion and triba ritual, Government Printers, Pretoria. (Ethnological publications, vol. III)

Van Warmelo, N.J. \& Phophi, W.M., 1948, Venda Law, Government Printer, Pretoria. Van Warmelo, N.J., 1995, Venda dictionary, Hippocrene, New York.

Walker, S.M., 2008, Hippopotamus, Lerner Publishing Group, Minneapolis.

Welsh, D. \& Spence, J.E., 2007, 'Ethnic demobilisation: The case of the Afrikaners', in A.S. Leoussi \& S. Grosby (eds.), Nationalism and ethno symbolism: History, culture and ethnicity in the formation of nations, pp. 281-297, Edinburgh University Press, Edinburg.

West, M., 1976, Abantu: An introduction to the Black people of South Africa Photographs by J. Morris, Struik, Cape Town.

Williams, R., 2001, The animator's survival kit, Faber and Faber, London.

Wright, J.A., 2005, Animation writing and development: From script development to pitch, Focal Press, New York. 